\title{
Effect of Intercropping on Sucking Insect Pests and Natural Enemies of Cotton
}

\author{
Suman Devi* \\ Department of Entomology, CCS Haryana Agricultural University Hisar-125004, \\ Haryana, India \\ *Corresponding author
}

\begin{tabular}{|c|}
\hline $\begin{array}{l}\text { Ke y w o r d s } \\
\text { Intercropping, } \\
\text { Insect pests, Cotton }\end{array}$ \\
\hline Article Info \\
\hline $\begin{array}{l}\text { Accepted: } \\
10 \text { March } 2018 \\
\text { Available Online: } \\
10 \text { April } 2018\end{array}$ \\
\hline
\end{tabular}

The main aim of the study was to reduce the maximum use of pesticides, these pesticides increases pest resurgence, environmental pollution and toxic residue in food. Efforts were being made to encourage those pest management practices which are ecofriendly. Pooled mean of both the years during 2016 and 2017 revealed that minimum population of leafhopper nymphs was recorded in cotton intercropped with bajra as border crop (2.47 nymphs/leaf) and maximum population was recorded in sole cotton (3.54 nymphs/leaf). Minimum population of thrips adults was recorded in cotton intercropped with bajra as border crop ( 2.24 adults/leaf) and maximum population in sole cotton (3.88 adults/leaf), and minimum population of whitefly adults was recorded in cotton intercropped with sorghum as border crop (2.52 adults/leaf) and maximum population in sole cotton (3.97 adults/leaf). In both the years 2016 and 2017, highest population of spiders and Chrysoperla spp. was recorded in cotton-sesame intercropping and lowest in sole cotton, and highest coccinellid beetles in cotton-pigeonpea intercropping system and lowest in sole cotton.

\section{Introduction}

Cultivating cotton as a sole crop is usually found to be risky and less remunerative. Intercropping in cotton is of significance because of higher profit and stabilized yield advantage, especially under adverse weather conditions. Some intercrops may act as barrier crops, some intercrops deter or others may attract insect pests of cotton and some intercrops attract natural enemies of insect pests. Natural enemies are organisms that kill, decrease the reproductive potential of, or otherwise reduce the numbers of another organism. Natural enemies that limit pests are key components of integrated pest management programs. Important natural enemies of insect pests include predators, parasitoids, and pathogens. A large number of natural enemies are associated with insect pests of cotton crop and these natural enemies are more in diverse crops as compared to sole crop. Sharma et al., (2009) revealed interplant maize/cowpea acted as source of predator due to diverse microhabitats, greater availability of food sources such as prey, nectar and pollen, all of which encouraged colonization and buildup of natural enemies, compared with 
cotton monoculture having lesser biodiversity. Effect of different intercrops like blackgram, soyabean, cowpea, setaria, pigeonpea, sorghum and maize was studied in cotton ecosystem. It was reported that these intercrops helped in the reduction of bollworm complex through the enhancement of predators like coccinellids and Chrysoperla. Highest population of Chrysoperla and coccinellids were observed in sorghum and maize (Rajput and Daware, 2002). There is increasing awareness about the ill effects of pesticide, particularly in terms of pest resurgence, environmental pollution and toxic residue in food. Hence, efforts are being made to encourage those pest management practices which are ecofriendly. Keeping this in view, the study was undertaken with this objective.

\section{Materials and Methods}

The population of leafhopper nymphs, adults of thrips and whitefly were recorded from three leaves, each one from top, middle and bottom canopies on six randomly selected plants per plot and observation were recorded at 10 days interval starting from 10 days after sowing. The observations recorded on sucking insect pests were later averaged to per leaf basis. The population of natural enemies was recorded after 15 days interval on six cotton plants selected randomly from each plot by beat bucket sampling method starting from first of July.

\section{Results and Discussion}

During 2016 the mean showed that minimum leafhopper nymphs population was recorded in cotton intercropped with bajra as border crop (2.86 nymphs/leaf) which was at par with cotton intercropped with sorghum as border crop (2.90 nymphs/leaf) and cotton-pigeonpea 1:1 (3.16 nymphs/leaf). Maximum population of leafhopper nymphs was recorded in sole cotton (3.97 nymphs/leaf) (Table 1). Among the intercrops, minimum population of leafhopper nymphs recorded in cotton intercropped with bajra as border crop (2.86 nymphs/leaf) followed by cotton intercropped with sorghum as border crop $(2.90$ nymphs/leaf), cotton-pigeonpea 1:1 (3.16 nymphs/leaf), cotton-pigeonpea $2: 1 \quad(3.20$ nymphs/leaf), cotton-sesame $1: 1 \quad$ (3.31 nymphs/leaf), cotton-sesame $2: 1 \quad$ (3.34 nymphs/leaf), cotton-pigeonpea $3: 1 \quad$ (3.41 nymphs/leaf) and highest in cotton-sesame 3:1 (3.42 nymphs/leaf). During 2017, mean population showed that minimum population of leafhopper nymphs was recorded in cotton intercropped with bajra as border crop (2.09 nymphs/leaf) which was at par with cotton intercropped with sorghum as border crop (2.09 nymphs/leaf). Maximum population of leafhopper nymphs was recorded in sole cotton (3.11 nymphs/leaf) and it was significantly different from all other treatments. Among the intercrops, minimum population of leafhopper nymphs recorded in cotton intercropped with bajra as border crop (2.09 nymphs/leaf) and cotton intercropped with sorghum as border crop (2.09 nymphs/leaf) followed by cotton-pigeonpea 1:1 (2.49 nymphs/leaf), cotton-pigeonpea 2:1 (2.58 nymphs/leaf), cotton-sesame 2:1 (2.61 nymphs/leaf), cotton-pigeonpea $3: 1 \quad(2.62$ nymphs/leaf), cotton-sesame 1:1 (2.62 nymphs/leaf) and highest in cotton-sesame 3:1 (2.78 nymphs/leaf).

Pooled mean of both the years during 2016 and 2017 revealed that minimum population of leafhopper nymphs was recorded in cotton intercropped with bajra as border crop (2.47 nymphs/leaf) which was at par with cotton intercropped with sorghum as border crop (2.49 nymphs/leaf). Maximum population was recorded in sole cotton (3.54 nymphs/leaf). Among the intercrops, lowest population of leafhopper was recorded in cotton intercropped with bajra as border crop (2.47 nymphs/leaf) followed by cotton intercropped 
with sorghum as border crop (2.49 nymphs/leaf), cotton-pigeonpea 1:1 (2.85 nymphs/leaf), cotton-pigeonpea $2: 1 \quad$ (2.87 nymphs/leaf), cotton-sesame $1: 1 \quad$ (2.96 nymphs/leaf), cotton-sesame 2:1 (2.97 nymphs/leaf), cotton-pigeonpea 3:1 (3.02 nymphs/leaf) and highest in cotton-sesame $3: 1$ (3.10 nymphs/leaf). The results are in agreement with Saminathan et al., (2002) and Kavitha et al., (2003) who reported that cotton-sorghum intercropping had minimum population of leafhopper and maximum population was found in sole cotton. Similarly, sorghum crop has been reported to act as a bio-reservoir for development of spider colony by Duffield (1995). The spider populations could have considerably suppressed the population of leafhopper due to their dense webbing and higher predating activity. Jambhunkar et al., (1998), Godhani (2006), Surulivelu, (2006) and Balakrishnan et al., (2010) also reported that intercropped cotton with pigeonpea suppressed the incidence of sucking pests over sole crop. The pigeonpea might have provided unfavourable microclimate and further, the allelochemicals might have deterred the sucking pests.

During 2016, mean revealed that minimum population of thrips adults was recorded in cotton intercropped with bajra as border crop (2.10 adults/leaf) which was at par with cotton intercropped with sorghum as border crop (2.25 adults/leaf). Maximum population of thrips adults was recorded in sole cotton (3.59 adults/leaf) which was at par with cottonsesame 2:1 (3.24 adults/leaf) and cottonsesame 3:1 (3.22 adults/leaf) (Table 2).

Among the intercrops, minimum population of thrips adults recorded in cotton intercropped with bajra as border crop (2.10 adults/leaf) followed by cotton intercropped with sorghum as border crop (2.25 adults/leaf), cottonpigeonpea 1:1 (2.76 adults/leaf), cottonsesame 1:1 (2.92 adults/leaf), cotton- pigeonpea 2:1 (2.93 adults/leaf), cottonpigeonpea 3:1 (3.02 adults/leaf), cottonsesame 3:1 (3.22 adults/leaf) and highest population of thrips was recorded in cottonsesame 2:1 (3.24 adults/leaf). During 2017, mean revealed that minimum population of thrips adults was recorded in cotton intercropped with sorghum as border crop (2.35 adults/leaf) which was at par with cotton intercropped with bajra as border crop (2.39 adults/leaf). Maximum population of thrips adults was recorded in sole cotton (4.16 adults/leaf) which was significantly different from all other treatments. Among the intercrops, minimum population of thrips recorded in cotton intercropped with sorghum as border crop (2.35 adults/leaf) followed by cotton intercropped with bajra as border crop (2.39 adults/leaf), cotton-pigeonpea 1:1 (3.15 adults/leaf), cotton-pigeonpea $2: 1 \quad$ (3.23 adults/leaf), cotton-pigeonpea $3: 1 \quad$ (3.31 adults/leaf), cotton-sesame $\quad 1: 1 \quad$ (3.38 adults/leaf), cotton-sesame $2: 1 \quad$ (3.53 adults/leaf) and highest population in cottonsesame 3:1 (3.64 adults/leaf).

Pooled mean of both the yeaars during 2016 and 2017, revealed that minimum population of thrips adults was recorded in cotton intercropped with bajra as border crop (2.24 adults/leaf) which was at par with cotton intercropped with sorghum as border crop (2.30 adults/leaf). Maximum population of thrips adults was recorded in sole cotton (3.88 adults/leaf). Among the intercrops, lowest population of thrips adults was recorded in cotton intercropped with bajra as border crop (2.24 adults/leaf) followed by cotton intercropped with sorghum as border crop (2.30 nymphs/leaf), cotton-pigeonpea 1:1 (2.96 adults/leaf), cotton-pigeonpea 2:1 (3.08 adults/leaf), cotton-sesame 1:1 (3.15 adults/leaf), cotton-pigeonpea $\quad 3: 1 \quad$ (3.17 adults/leaf), cotton-sesame 2:1 (3.39 adults/leaf), and highest population in cottonsesame 3:1 (3.43 adults/leaf). The results are 
in accordance with Rafee (2010) who reported that intercropping of cotton with sorghum resulted in low infestation of thrips (1.82 thrips/leaf) followed by cotton-cowpea (1.83 thrips/leaf), cotton-sesame (1.93 thrips/leaf) and highest in sole cotton (2.20 thrips/leaf). Godhani (2006) and Kadam et al., (2014) also concluded that lower incidence of thrips was found in cotton intercropped with sesame over sole cotton. The reduction in pests incidence in intercropped cotton may be due to low resources concentration or due to abundance of natural enemies. Similar finding was reported by Balasubramanyam et al., (1998) who reported that intercropping system had low infestation of sucking pests such as whiteflies, leafhoppers, aphids and thrips over sole cotton.

During 2016, mean revealed that minimum population of whitefly adults was recorded in cotton intercropped with sorghum as border crop (2.54 adults/leaf) which was at par with cotton intercropped with bajra as border crop (2.58 adults/leaf) (Table 3). Maximum population of whitefly adults was recorded in sole cotton (4.03 adults/leaf) which was at par with cotton-sesame 3:1 (3.75 adults/leaf).

Among the intercrops, minimum population of whitefly adults recorded in cotton intercropped with sorghum as border crop (2.54 adults/leaf) followed by cotton intercropped with bajra as border crop (2.58 adults/leaf), cotton-pigeonpea 1:1 (2.90 adults/leaf), cotton-sesame $\quad 1: 1 \quad$ (3.16 adults/leaf), cotton-pigeonpea $2: 1 \quad$ (3.36 adults/leaf), cotton-pigeonpea $3: 1 \quad$ (3.46 adults/leaf), cotton-sesame 2:1 (3.60 adults/leaf) and highest population of whitefly was in cotton-sesame 3:1 (3.75 adults/leaf).

During 2017, revealed that minimum population of whitefly adults was recorded in cotton intercropped with sorghum as border crop (2.61 adults/leaf) which was at par with cotton intercropped with bajra as border crop (2.72 adults/leaf) and cotton-pigeonpea 1:1 (3.04 adults/leaf). Maximum population was recorded in sole cotton (4.01 adults/leaf) which was at par with cotton-sesame 3:1 (3.80 adults/leaf). Among the intercrops, minimum population of whitefly adults recorded in cotton intercropped with sorghum as border crop (2.61 adults/leaf) followed by cotton intercropped with bajra as border crop (2.72 adults/leaf), cotton-pigeonpea 1:1 (3.04 adults/leaf), cotton-pigeonpea 2:1 (3.30 adults/leaf), cotton-pigeonpea $3: 1 \quad$ (3.46 adults/leaf) and cotton-sesame 1:1 (3.46 adults/leaf), cotton-sesame $2: 1 \quad$ (3.63 adults/leaf) and highest in cotton-sesame 3:1 (3.80 adults/leaf).

Pooled mean of both the years during 2016 and 2017 revealed that minimum population of whitefly adults was recorded in cotton intercropped with sorghum as border crop (2.52 adults/leaf) which was at par with cotton intercropped with bajra as border crop (2.61 adults/leaf). Maximum population of whitefly adults was recorded in sole cotton (3.97 adults/leaf) which at par with cotton-sesame 3:1 (3.66 adults/leaf). Among the intercrops, lowest population of whitefly adults was recorded in cotton intercropped with sorghum as border crop (2.52 adults/leaf) followed by cotton intercropped with bajra as border crop (2.61 adults/leaf), cotton-pigeonpea 1:1 (2.93 adults/leaf), cotton-sesame 1:1 (3.26 adults/leaf), cotton-pigeonpea 2:1 (3.29 adults/leaf), cotton-pigeonpea $3: 1 \quad$ (3.44 adults/leaf), cotton-sesame 2:1 (3.61 adults/leaf), and highest in cotton-sesame 3:1 (3.66 adults/leaf). The results are in agreement with Jambhunkar et al., (1998) who reported that intercropping cotton with legumes reduced the incidence of whitefly. This might be due to the reason that when tall growing plants are intercropped in cotton, these might reduce the whitefly dispersal and avoid them to land on the cotton crop. 


\section{Materials and Methods}

\begin{tabular}{|c|c|}
\hline Dates of sowing & $\begin{array}{l}14^{\text {th }} \text { May and } 11^{\text {th }} \text { May during } 2016 \text { and } 2017 \text { for cotton, and } 2^{\text {th }} \text { June and } 4^{\text {th }} \\
\text { June during } 2016 \text { and } 2017 \text { for intercrops in the experimental area of } \\
\text { Department of Entomology, CCS Haryana Agricultural University, Hisar. }\end{array}$ \\
\hline Design & Randomized Block Design \\
\hline No. of replication & Three \\
\hline No. of treatments & Nine \\
\hline $\begin{array}{ll}\text { Row to row } \\
\text { distance }\end{array}$ & $67.5 \times 30 \mathrm{~cm}$ \\
\hline Intercrops & $\begin{array}{l}\text { (1) Cotton+Sesame (1:1) } \\
\text { (2)Cotton+Sesame (2:1) } \\
\text { (3) Cotton+Sesame }(3: 1) \\
\text { (4) Cotton+Pigeonpea }(1: 1) \\
\text { (5) Cotton+Pigeonpea }(2: 1) \\
\text { (6) Cotton+Pigeonpea }(3: 1) \\
\text { (7) A row of Sorghum around cotton plot } \\
\text { (8) A row of bajra around cotton plot }\end{array}$ \\
\hline $\begin{array}{l}\text { Varieties:- } \\
\text { Desi cotton } \\
\text { Sesame } \\
\text { Pigeonpea } \\
\text { Sorghum } \\
\text { Bajra }\end{array}$ & $\begin{array}{l}\text { HD-432 } \\
\text { HT-1 } \\
\text { Paras } \\
\text { HC-171 } \\
\text { HHB-67i }\end{array}$ \\
\hline
\end{tabular}

Table.1 Effect of intercropping on population of leafhopper nymphs in cotton

\begin{tabular}{|l|}
\hline Treatments \\
\hline Cotton+Sesame 1:1 \\
\hline Cotton+Sesame 2:1 \\
\hline Cotton+Sesame 3:1 \\
\hline Cotton+Pigeonpea 1:1 \\
\hline Cotton+Pigeonpea 2:1 \\
\hline Cotton+Pigeonpea 3:1 \\
\hline Cotton+ Bajira (border crop) \\
\hline Cotton+Sorghum (border \\
crop) \\
\hline Sole Cotton \\
\hline SE \pm (m) \\
\hline CD at 5\% \\
\hline
\end{tabular}

\begin{tabular}{|c|c|c|}
\hline \multicolumn{3}{|c|}{ Mean number of leafhopper nymphs per leaf } \\
\hline $\mathbf{2 0 1 6}$ & $\mathbf{2 0 1 7}$ & Pooled mean \\
\hline $3.31(2.01)$ & $2.62(1.83)$ & $2.96(1.93)$ \\
\hline $3.34(2.01)$ & $2.61(1.82)$ & $2.97(1.93)$ \\
\hline $3.42(2.04)$ & $2.78(1.87)$ & $3.10(1.96)$ \\
\hline $3.16(1.96)$ & $2.49(1.79)$ & $2.85(1.89)$ \\
\hline $3.20(1.98$ & $2.58(1.81)$ & $2.87(1.90)$ \\
\hline $3.41(2.03)$ & $2.62(1.83)$ & $3.02(1.94)$ \\
\hline $2.86(1.90)$ & $2.09(1.70)$ & $2.47(1.81)$ \\
\hline $2.90(1.91)$ & $2.09(1.70)$ & $2.49(1.81)$ \\
\hline $3.97(2.25)$ & $3.11(1.95)$ & $3.54(2.06)$ \\
\hline$(\mathbf{0 . 0 2})$ & $(\mathbf{0 . 0 2})$ & $\mathbf{( 0 . 0 2})$ \\
\hline $\mathbf{( 0 . 0 6}$ & $(\mathbf{0 . 0 6})$ & $\mathbf{( 0 . 0 5})$ \\
\hline
\end{tabular}

Figures in parentheses are square root transformed values 
Table.2 Effect of intercropping on population of thrips adults in cotton

\begin{tabular}{|l|c|c|c|}
\hline \multirow{2}{*}{ Treatments } & \multicolumn{3}{|c|}{ Mean number of thrips adults per leaf } \\
\hline Cotton+Sesame 1:1 & $\mathbf{2 0 1 6}$ & $\mathbf{2 0 1 7}$ & Pooled mean \\
\hline Cotton+Sesame 2:1 & $2.92(1.89)$ & $3.38(2.00)$ & $3.15(1.95)$ \\
\hline Cotton+Sesame 3:1 & $3.24(1.97)$ & $3.53(2.04)$ & $3.39(2.02)$ \\
\hline Cotton+Pigeonpea 1:1 & $3.22(1.96)$ & $3.64(2.07)$ & $3.43(2.03)$ \\
\hline Cotton+Pigeonpea 2:1 & $2.76(1.84)$ & $3.15(1.95)$ & $2.96(1.90)$ \\
\hline Cotton+Pigeonpea 3:1 & $2.93(1.89)$ & $3.23(1.97)$ & $3.08(1.94)$ \\
\hline Cotton+ Bajra (border crop) & $3.02(1.90)$ & $3.31(1.98)$ & $3.17(1.95)$ \\
\hline Cotton+Sorghum (border crop) & $2.10(1.69)$ & $2.39(1.77)$ & $2.24(1.73)$ \\
\hline Sole Cotton & $2.25(1.73)$ & $2.35(1.75)$ & $2.30(1.75)$ \\
\hline SE $\pm(m)$ & $3.59(2.03)$ & $4.16(2.19)$ & $3.88(2.12)$ \\
\hline CD at 5\% & $\mathbf{( 0 . 0 3 )}$ & $\mathbf{( 0 . 0 2})$ & $(\mathbf{0 . 0 2})$ \\
\hline Figur| & $\mathbf{( 0 . 0 9 )}$ & $\mathbf{( 0 . 0 6})$ & $(\mathbf{0 . 0 6})$ \\
\hline
\end{tabular}

Figures in parentheses are square root transformed values

Table.3 Effect of intercropping on population of whitefly adults in cotton

\begin{tabular}{|l|}
\hline Treatments \\
\hline Cotton+Sesame 1:1 \\
\hline Cotton+Sesame 2:1 \\
\hline Cotton+Sesame $3: 1$ \\
\hline Cotton+Pigeonpea $1: 1$ \\
\hline Cotton+Pigeonpea 2:1 \\
\hline Cotton+Pigeonpea 3:1 \\
\hline Cotton+ Bajra (border crop) \\
\hline Cotton+Sorghum (border crop) \\
\hline Sole Cotton \\
\hline SE \pm (m) \\
\hline CD at $5 \%$ \\
\hline
\end{tabular}

\begin{tabular}{|c|c|c|}
\hline \multicolumn{3}{|c|}{ Mean number of whitefly adults per leaf } \\
\hline $\mathbf{2 0 1 6}$ & $\mathbf{2 0 1 7}$ & Pooled mean \\
\hline $3.16(1.99)$ & $3.46(2.03)$ & $3.26(2.01)$ \\
\hline $3.60(2.10)$ & $3.63(2.05)$ & $3.61(2.08)$ \\
\hline $3.75(2.12)$ & $3.80(2.11)$ & $3.66(2.10)$ \\
\hline $2.90(1.92)$ & $3.04(1.93)$ & $2.93(1.93)$ \\
\hline $3.36(2.04)$ & $3.30(2.00)$ & $3.29(2.02)$ \\
\hline $3.46(2.05)$ & $3.46(2.03)$ & $3.44(2.04)$ \\
\hline $2.58(1.85)$ & $2.72(1.87)$ & $2.61(1.85)$ \\
\hline $2.54(1.84)$ & $2.61(1.84)$ & $2.52(1.83)$ \\
\hline $4.03(2.18)$ & $4.01(2.15)$ & $3.97(2.16)$ \\
\hline$(\mathbf{0 . 0 3})$ & $\mathbf{( 0 . 0 3 )}$ & $\mathbf{( 0 . 0 3 )}$ \\
\hline$(\mathbf{0 . 0 7})$ & $\mathbf{( 0 . 0 9 )}$ & $(\mathbf{0 . 0 7})$ \\
\hline
\end{tabular}

Figures in parentheses are square root transformed values

Table.4 Effect of intercropping on natural enemies population in cotton during 2016

\begin{tabular}{|l|c|c|c|}
\hline Treatments & Spiders/plant & Coccinellids/plant & $\begin{array}{c}\text { Chrysperla adults } \\
\text { /plant }\end{array}$ \\
\hline Cotton+Sesame 1:1 & $1.83(1.65)$ & $1.16(1.44)$ & $0.59(1.25)$ \\
\hline Cotton+Sesame 2:1 & $1.68(1.60)$ & $1.01(1.39)$ & $0.54(1.23)$ \\
\hline Cotton+Sesame 3:1 & $1.32(1.49)$ & $0.98(1.39)$ & $0.49(1.21)$ \\
\hline Cotton+Pigeonpea 1:1 & $1.50(1.55)$ & $1.41(1.52)$ & $0.38(1.17)$ \\
\hline Cotton+Pigeonpea 2:1 & $1.31(1.49)$ & $1.37(1.51)$ & $0.33(1.15)$ \\
\hline Cotton+Pigeonpea 3:1 & $1.13(1.44)$ & $1.31(1.49)$ & $0.32(1.14)$ \\
\hline Cotton+Bajra (border crop) & $0.95(1.38)$ & $0.80(1.32)$ & $0.37(1.16)$ \\
\hline Cotton+Sorghum (border crop) & $0.90(1.37)$ & $0.75(1.30)$ & $0.44(1.18)$ \\
\hline Sole Cotton & $0.88(1.36)$ & $0.74(1.30)$ & $0.28(1.12)$ \\
\hline SE $(\mathbf{m})$ & $\mathbf{( 0 . 0 5 )}$ & $\mathbf{( 0 . 0 4 )}$ & $\mathbf{( 0 . 0 4 )}$ \\
\hline CD at 5\% & $\mathbf{( 0 . 1 4 )}$ & $\mathbf{( 0 . 1 0 )}$ & $\mathbf{( 0 . 0 2}$ \\
\hline
\end{tabular}

Figures in parentheses are square root transformed values 
Table.5 Effect of intercropping on natural enemies population in cotton during 2017

\begin{tabular}{|l|c|c|c|}
\hline Treatments & Spiders/plant & Coccinellids/plant & Chrysperla adults /plant \\
\hline Cotton+Sesame 1:1 & $2.30(1.80)$ & $1.23(1.47)$ & $0.33(1.13)$ \\
\hline Cotton+Sesame 2:1 & $2.13(1.76)$ & $1.02(1.40)$ & $0.24(1.12)$ \\
\hline Cotton+Sesame 3:1 & $1.67(1.62)$ & $0.97(1.38)$ & $0.23(1.10)$ \\
\hline Cotton+Pigeonpea 1:1 & $1.90(1.69)$ & $1.44(1.53)$ & $0.21(1.09)$ \\
\hline Cotton+Pigeonpea 2:1 & $1.67(1.62)$ & $1.36(1.50)$ & $0.20(1.09)$ \\
\hline Cotton+Pigeonpea 3:1 & $1.50(1.57)$ & $1.31(1.50)$ & $0.16(1.07)$ \\
\hline Cotton+ Bajira (border crop) & $1.68(1.63)$ & $0.80(1.33)$ & $0.17(1.08)$ \\
\hline Cotton+Sorghum (border & $1.58(1.60)$ & $0.77(1.32)$ & $0.17(1.08)$ \\
crop) & $1.40(1.54)$ & $0.75(1.31)$ & $0.14(1.06)$ \\
\hline Sole Cotton & $\mathbf{( 0 . 0 5 )}$ & $\mathbf{( 0 . 0 3 )}$ & $\mathbf{( 0 . 0 2 )}$ \\
\hline SE $\mathbf{( m )}$ & $\mathbf{( 0 . 1 5 )}$ & $\mathbf{( 0 . 1 1 )}$ & $\mathbf{( 0 . 0 1 )}$ \\
\hline CD at 5\% &
\end{tabular}

Figures in parentheses are square root transformed values

Tall growing nature of bajra and sorghum might have reduced the activity of whitefly, which always prefers to travel on the top level. Similarly, Patel (2001) reported that cotton intercropping with sesame had low incidence of sucking pests as compared to sole cotton. Rafee (2010) also concluded that cotton-sorghum intercropping resulted in low infestation of whitefly ( 0.19 adults/leaf) followed by cottoncowpea ( 0.20 adults/leaf), cotton-sesame $(0.21$ adults/leaf), and highest in sole cotton (0.30 adults/leaf).

The date on table 4 revealed that maximum population of spiders was recorded in cottonsesame 1:1 (1.83 spiders/plant) which was at par with cotton-pigeonpea 1:1 (1.50 spiders/plant) and cotton-sesame 2:1 (1.68 spiders/plant). Minimum population of spiders was recorded in sole cotton ( 0.88 spiders/plant) which was at par with cotton intercropped with sorghum as border crop (0.90 spiders/plant), cotton intercropped with bajra as border crop (0.95 spiders/plant), cotton-pigeonpea 3:1 (1.13 spiders/plant), cotton-pigeonpea 2:1 (1.31 spiders/plant) and cotton-sesame 3:1 (1.32 spiders/plant). The results of the present study are in agreement with those of Patel (2001) and Kadam et al., (2014) who concluded that cotton intercropping with sesame enhanced arthropod natural enemies of cotton pests i.e. spiders. Similarly, Venugopala et al., (1995) and Mote et al., (2001) reported that maximum spiders population were found in cotton intercropped with pigeonpea and lowest in sole cotton.

The data on table 4 revealed that maximum population of coccinellid beetles was observed in cotton-pigeonpea $1: 1$ (1.41 beetles/plant) which was at par with cotton-sesame 1:1 (1.16 beetles/plant), cotton-pigeonpea 3:1 (1.31 beetles/plant) and cotton-pigeonpea 2:1 (1.37 beetles/plant). Minimum population of coccinellid beetles was recorded in sole cotton (0.74 beetles/plant) which was at par with cotton intercropped with sorghum as border crop ( 0.75 beetles/plant), cotton intercropped with bajra as border crop ( 0.80 beetles/plant), cotton-sesame 3:1 (0.98 beetles/plant) and cotton-sesame 2:1 (1.01 beetles per plant). The results of present study are in agreement with those of Venugopal et al., (1995) and Mote et al., (2001) who reported that maximum coccinellids were found in pigeonpea and lowest in sole cotton. Lester and Furr (1972) and Kadam et al., (2014) also reported that cotton-sesame inter-planting ecosystem favoured buildup of ladybird beetles over the sole cotton. Kavitha et al., (2003) and Scholz and Parker (2004) reported that lady bird 
beetles were one of the main predators in cotton adjacent to sorghum. These results are in conformity with those of Patel (2001) and Kadam et al., (2014) who reported that maximum predators were found in cottonsesame and minimum in sole cotton.

The data on table 4 revealed that maximum population of Chrysoperla spp. was recorded in cotton-sesame 1:1 (0.59 grubs and adults/plant) which was at par with cotton-sesame 2:1 (0.54 grubs and adults/plant). Minimum population of Chrysoperla spp. was recorded in sole cotton (0.28 grubs and adults/plant) which was at par with cotton-pigeonpea $3: 1 \quad(0.32$ grubs and adults/plant). Similarly, Venugopal et al., (1995) and Kranthi and Russell (2009) reported that maximum number of Chrysoperla spp. were found in pigeonpea and lowest in sole cotton. Rajput and Daware (2002) and Hegde et al., (2004) also reported that cotton-sorghum intercropping enhanced the activity of Chrysoperla spp. over sole cotton.

The data on table 5 revealed that maximum population of spiders was recorded in cottonsesame 1:1 (2.30 spiders/plant) which was at par with cotton-sesame $2: 1$ (2.13 spiders/plant) and cotton-pigeonpea 1:1 (1.90 spiders/plant). Minimum population of spiders was recorded in sole cotton (1.40 spiders/plant) which was at par with cotton intercropped with bajra as border crop (1.68 spiders/plant), cotton intercropped with sorghum as border crop (1.58 spiders/plant), cotton-sesame $3: 1 \quad(1.67$ spiders/plant), cotton-pigeonpea 1:1 (1.90 spiders/plant), cotton-pigeonpea $2: 1 \quad(1.67$ spiders/plant) and cotton-pigeonpea 3:1 (1.50 spiders/plant). The results of the present study are in agreement with those of Patel (2001) and Kadam et al., (2014) who concluded that cotton intercropping with sesame enhanced arthropod natural enemies of cotton pests i.e. spiders.

The data on table 5 revealed that maximum population of coccinellid beetles was observed on cotton-pigeonpea 1:1 (1.44 beetles/plant) which was at par with cotton-sesame 1:1 (1.23 beetles/plant), cotton-pigeonpea $3: 1 \quad(1.31$ beetles/plant) and cotton-pigeonpea 2:1 (1.36 beetles/plant). Minimum population of coccinellid beetles was recorded in sole cotton (0.75 beetles/plant) which was at par with cotton-sesame 3:1 (0.97 beetles/plant), cottonsesame $2: 1 \quad(1.02$ beetles/plant $)$ cotton intercropped with bajra as border crop (0.80 beetles/plant) and cotton intercropped with sorghum as border crop ( 0.77 beetles/plant).

The data on table 5 revealed that maximum population of Chrysoperla spp. was recorded in cotton-sesame 1:1 (0.33 grubs and adults/plant) and it was at par with cotton-sesame 2:1 (0.24 grubs and adults/plant) and minimum population of Chrysoperla spp. was recorded in sole cotton ( 0.14 grubs and adults/plant) which was at par with cotton- pigeonpea 3:1 (0.16 grubs and adults/plant).

\section{References}

Balakrishnan, N., Murali, B.R.K. and Mahadevan, N.R. 2010. Influence of intercrops/trap crops on the preference of major pests of cotton in different IPM modules under rainfed conditions. Journal of Biopesticides. 3: 373-378.

Balasubramanyam, A., Mahadevan, N.R., Venugopal, M.S. and Murali, B.R.K. 1998. Influence of intercropping on infestation of early season sucking pests of cotton (Gossypium hirsutum). Indian Journal of Agricultural Science. 68 (6): 315-16.

Duffield, S.J. (1995). Crop specific differences in the seasonal abundance of four major predatory groups on sorghum and short duration pigeonpea. International Chickpea and Pigeonpea Newsletter. 2: 74-76.

Godhani, P.H. 2006. Impact of intercropping on the insect pests suppression in Hybrid cotton-10. Ph.D Thesis submitted to Anand Agricultural University, Anand, India.

Hegde, M.G., Kulkarni, K.A. and Lingappa, S. 2004. Influence of intercrops on bollworms and natural enemies in cotton. 
Proceedings of International Symposium on "Strategies for Sustainable Cotton Production-A Global Vision 3" held from November 23-25, 2004 at University of Agricultural Sciences, Dharwad, Karnataka, India. pp. 219-223.

Jambhrunkar, S.R., Nachane, M.N., Sonalkar, V.U. and Sadawarte, A.K. 1998. Management of sucking pests in cotton through cropping systems. Journal of Soils and Crops. 8: 50-52.

Kadam, D.B., Kadam, D.R. and Lekurwale, R.S. 2014. Seasonal incidence of sucking pests of $B t$ cotton in different intercropping systems and their natural enemies. Journal of Plant and Pest Science. 1: 29-34.

Kavitha, G., Ram, P and Saini, R.K. 2003. Impact of strip crops on the population of arthropod predators and insect pests in cotton. Journal of Biological Control. 17:17-21.

Kranthi, K.R. and Russell, D.A. 2009. Changing trends in cotton pest management-Integrated Pest Management. Innovative-Development Process. pp. 499-541.

Lester, M.L. and Furr, R.E. 1972. Heliothis populations in cotton sesame inter plantings. Journal of Economic Entomology. 65: 1524-1525.

Mote, U.N., Patil, M.B. and Tambe, A.B. 2001. Role of intercropping in population dynamic of major pests cotton ecosystem. Annals of Plant Proection Sciences. 9: 36-40.

Patel, H.M. 2001. Habitat manipulation in Hybrid cotton-10 and evaluation of subsequent arthropod natural enemies on insect pests. Ph. D. thesis submitted to Gujarat Agricultural University, Sardar Krushinaga, India.
Rafee, C.M. 2010. Insect pest management in desi cotton. Ph.D. Thesis submitted to Department of Agricultural Entomology, College of Agriculture, Dharwad University of Agricultural Sciences, Dharwad, Karnataka.

Rajput, K.P. and Daware, D.G. 2002. Effects of different intercrops on the population buildup of Chrysoperla and coccinellids on cotton. Journal of Cotton Research and Development. 16:106-107.

Saminathan, V.R., Mahadevan, N.R. and Muthukrishnan, N. 2002. Crop diversity approach to manage cotton leafhopper, Amrasca devastans. Indian Journal of Entomology. 64: 351-357.

Scholz, B. and Parker, N. 2004. The nursery value of sorghum intercropped with cotton-The effects of Heliothis egg parasitism and predator abundance. $11^{\text {th }}$ Australian cotton conference proceedings 1-10. Theme: Quality cotton a living industry not just another yarn held on 1012 August, 2004. Broadbeach, Queensland. Australian

Sharma, O.P., Lavekar, R.C., Murthy, K.S. and Puri, S.N. 2009. Habitat diversity and predatory insects in cotton IPM: case study of Maharashtra cotton eco-system. IPM World Textbook. University of Minnesota (USA). pp. 1-5.

Surulivelu, T. 2006. Pest Control in Organic Cotton-Crop Protection Folder, Central Institute for Cotton Research, Regional Station Coimbatore. pp. 1-2.

Venugopala, R.N., Rajasekhar, P., Venkataiah, M. and Rajasri, M. 1995. Influence of habitat on Helicoverpa armigera (Hubner) in cotton ecosystem. Indian Journal of Plant Protection. 23: 122-125.

\section{How to cite this article:}

Suman Devi. 2018. Effect of Intercropping on Sucking Insect Pests and Natural Enemies of Cotton. Int.J.Curr.Microbiol.App.Sci. 7(04): 1101-1109. doi: https://doi.org/10.20546/ijcmas.2018.704.120 